\title{
A Psorosis-Like Agent Prevalent in Florida's Grapefruit Groves and Budwood Sources
}

C. A. Powell, R. R. Pelosi, and R. M. Sonoda, University of Florida, IFAS, Indian River Research and Education Center, Fort Pierce 34945-3138; and R. F. Lee, University of Florida, IFAS, Citrus Research and Education Center, Lake Alfred 33850-2299

\begin{abstract}
Powell, C. A., Pelosi, R. R., Sonoda, R. M., and Lee, R. F. 1998. A psorosis-like agent prevalent in Florida's grapefruit groves and budwood sources. Plant Dis. 82:208-209.

Rio Grande Gummosis (RGG) is one of the most serious diseases of grapefruit in the Indian River region of Florida. Experiments were conducted to determine if a graft-transmissible agent was associated with this disease in commercial grapefruit, and if any such agent was present in scion sources used for grapefruit propagation. Indexing data from indicators revealed that $79 \%$ and $31 \%$ of the commercial grapefruit and scion trees, respectively, contained a psorosis-like agent (PLA). The PLA was present in both RGG-affected and symptomless trees. We conclude that Florida's grapefruit propagation sources are contaminated with a PLA that is now widespread in commercial plantings.
\end{abstract}

The term "citrus psorosis" has been used to refer to several diseases that may not have a common causal agent. It was the first citrus disease recognized to be caused by a graft-transmissible agent (4) and the first disease to be diagnosed by use of a seedling index (12). It was present in most old-line budwood sources, and was reported in Florida in 1896 (10). Symptoms include leaf flecking, bark scaling, gumming, and dieback. Names for virus diseases causing psorosis-like symptoms on indicator plants include psorosis A, psorosis $\mathrm{B}$, citrus ringspot, concave gum, impietratura, and cristacortis $(6,11)$. Psorosis $\mathrm{A}$ and $\mathrm{B}$ are mild and severe forms, respectively, of the same virus disease. Citrus ringspot virus is the same strain as psorosis B.

Concave gum, impiertratura, and cristacortis are different agents than citrus ringspot virus, and can be distinguished from true psorosis viruses on indicators. A recent review of psorosis and psorosis-like agents has been published (7).

The citrus psorosis disease is usually controlled through budwood certification programs in which the causal agent has been eliminated. However, recent evidence suggests that there are psorosis-like agents

Corresponding author: C. A. Powell

E-mail: capo@gnv.ifas.ufl.edu

This project was funded by a grant from the Florida Production Research Advisory Council.

Florida Agricultural Experiment Station Journal Series R-05402.

Accepted for publication 10 October 1997.

Publication no. D-1997-1208-06R

(C) 1998 The American Phytopathological Society
(PLA) that may escape detection using current indexing procedures, because symptom development in indicators has strict temperature (cool night $\left[18\right.$ to $\left.20^{\circ} \mathrm{C}\right]-$ warm day [35 to $\left.40^{\circ}\right]$ ) requirements.

Rio Grande Gummosis (RGG) is a serious disease problem in grapefruit on the east coast of Florida. This disorder, also called Florida gummosis and, in California, ferment gum disease (1), is characterized by cracks in the bark which release a yellow gum. Gum pockets form beneath the bark, and the internal wood may become infiltrated with the gum. These symptoms develop on the trunk and may expand into the main scaffold branches and secondary branches, as well. Trees with RGG usually become unproductive over a period of years and may eventually die or be removed. In recent years, RGG incidence has increased in the Indian River region of Florida. Percentages of diseased trees in groves surveyed ranged from 3 to $74 \%$, with the highest incidence of the disease in older groves (5). Previously, RGG occurred primarily in groves at least 20 years old; however, now some groves (RGG) less than 10 years old have a disease incidence of greater than $10 \%$ (5).

The cause of RGG is unknown. A fungus, Physalospora rhodina (Berk and Curt.), has been isolated from RGG lesions (3) and can cause typical RGG symptoms. However, other fungi have also been implicated (3). The disorder has also been reported to be caused by high chloride in irrigation water (2). Spatial patterns (8) and disease progress curves (9) suggest that RGG has an abiotic etiology. Symptoms caused by RGG resemble the barkscaling symptoms caused by psorosis, but differ from them in that less gumming is induced from the bark cracks and callus tissue is formed beneath the bark cracks (11). Inspection of grapefruit trees affected with RGG suggests that psorosis might be involved in at least part of the instances which are commonly being called RGG.

We report here the results of surveys conducted to determine if a PLA is present in Florida "Ruby Red" grapefruit groves and in grapefruit budwood propagation sources, and if the presence of this agent correlates with RGG symptoms.

\section{MATERIALS AND METHODS}

Trees in five commercial Ruby Red grapefruit (Citrus paradisi Macf.) groves in the Indian River region (within $16 \mathrm{~km}$ of Fort Pierce, Florida) that had been mapped for RGG distribution for the previous 5 years were selected for indexing for PLA. Groves ranged in age from 13 to 40 years, and at least $10 \%$ of trees showed RGG symptoms (Table 1). During the winter, at each of the five sites, 5 budwood sticks were collected from different locations within the canopy of 5 healthy-appearing (no RGG symptoms) and 5 RGG-affected

Table 1. Assay for psorosis-like agents in Ruby Red grapefruit affected by Rio Grande Gummosis

\begin{tabular}{cccc}
\hline Grove location $^{\mathbf{a}}$ & Tree condition & Tree age (years) & Trees positive $\mathbf{b}$ trees tested \\
\hline 1 & Symptomless & 13 & $3 / 4$ \\
1 & RGG-affected & 13 & $3 / 4$ \\
2 & Symptomless & $20-28$ & $3 / 5$ \\
2 & RGG-affected & $20-28$ & $5 / 5$ \\
3 & Symptomless & 18 & $3 / 5$ \\
3 & RGG-affected & 18 & $4 / 5$ \\
4 & Symptomless & $>40$ & $4 / 5$ \\
4 & RGG-affected & 40 & $5 / 5$ \\
5 & Symptomless & 24 & $4 / 5$ \\
5 & RGG-affected & 24 & $4 / 5$ \\
\hline
\end{tabular}

a All sites are located in the Indian River region within $16 \mathrm{~km}$ of Fort Pierce, Florida.

${ }^{\mathrm{b}}$ Madam Vinous or Duncan grapefruit indicators showed vein-flecking or vein-clearing patterns. 
Table 2. Assay for psorosis-like agents in Ruby Red grapefruit used as budwood sources for commercial propagation

\begin{tabular}{lc}
\hline Budwood source & Trees positivea/trees tested \\
\hline Commercial nursery \#1 & $2 / 7$ \\
Commercial nursery \#2 & $6 / 9$ \\
Commercial nursery \#3 & $6 / 10$ \\
Commercial nursery \#4 & $5 / 19$ \\
Commercial nursery \#5 & $2 / 11$ \\
State foundation block & $3 / 16$ \\
University of Florida Foundation block & $0 / 5$ \\
Total & $24 / 77$ \\
\hline
\end{tabular}

${ }^{a}$ Madam Vinous or Duncan grapefruit indicators showed vein-flecking or vein-clearing patterns.

trees. Budsticks were stored overnight at $4^{\circ} \mathrm{C}$ and used the next day to inoculate Madam Vinous sweet orange ( $C$. sinensis (L.) Osbeck) and Duncan grapefruit seedlings. The inoculation/indexing procedure consisted of placing a bud chip from each budstick into an indicator plant using a Tgraft. Thus, each grapefruit tree was indexed on 5 Madam Vinous and 5 Duncan grapefruit indicators. The indicator plants were maintained in a greenhouse with a 18 to $20^{\circ} \mathrm{C}$ night $/ 35$ to $40^{\circ} \mathrm{C}$ day temperature regime. Bud take was checked and recorded after 21 days. Indicators were observed for mild vein-flecking or veinclearing 3 to 4 times a week for two growth flushes (about 6 weeks). A tree was scored as positive if either symptom developed on an indicator plant. Previous results have shown this indexing regime to be almost $100 \%$ effective in detecting psorosis (R. F. Lee, unpublished data).

A second survey was conducted to test Florida grapefruit budwood sources for PLA. The survey consisted of 5 to 10 trees from each of five commercial grapefruit nurseries and two foundation plantings (Table 2). Budwood collection and indexing procedures were as described above.

\section{RESULTS}

The results of the survey of Ruby Red grapefruit in commercial groves for PLA indicated that $79 \%$ of the trees were infected (Table 1). There was little difference in the level of infection among trees that had RGG symptoms (88\%) compared to those that were symptomless $(71 \%)$. There were 3 trees with RGG in which a PLA was not detected. Many trees without RGG symptoms contained a PLA.

The second survey of budwood sources used for commercial Ruby Red grapefruit propagation showed that $31 \%$ of these scion trees contained a PLA. Only the foundation planting at the University of Florida in Immokalee was free of the agent. The high percentage of infection of grapefruit propagation sources partially explains the high incidence of PLA in commercial grapefruit groves.

\section{DISCUSSION}

The finding that $79 \%$ of the commercial grapefruit from five groves and $31 \%$ of the Ruby Red grapefruit from seven propagation sources were infected with a PLA was unexpected. The likely reason for this is that Florida's Citrus Budwood Registration Program, established in 1952 to eliminate psorosis, did not require indexing under recommended temperature regimes (10). Indexing procedures for psorosis in budwood source trees consisted of an annual observation of the trees in the field. Therefore, some PLA that were only detectable under cool night $\left(18\right.$ to $20^{\circ} \mathrm{C}$ )/warm day ( 35 to $40^{\circ} \mathrm{C}$ ) temperatures were propagated and widely distributed. Indexing procedures for some certified trees have been changed to address the environmental effects on symptom development, and PLAfree grapefruit are currently available.

The vein-flecking or vein-clearing in the indicators was less conspicuous than the severe ringspots and flush dieback caused by citrus ringspot virus. The PLA detected in groves and budwood sources in Florida is probably different than citrus ringspotrelated psorosis agents.

The fact that the percentage of PLA in propagating sources is less than that in commercial groves may indicate that the agent can spread among trees by some natural means. This potential movement would be slow, since not all the trees in the scion groves, some of which have been established for several years, are infected.
Our results do not answer the question of whether the PLA is involved with RGG, but they do not eliminate it as a factor in the disease. Even with improved indexing procedures, symptoms can be difficult to detect in indicator trees. It is possible that the 3 trees with RGG symptoms that assayed negative for psorosis were false negatives. Symptomless trees with a PLA probably require other factors in order to develop symptoms. An experiment using grapefruit inoculated with a PLA is under way to determine the role of the PLApositive budwood in RGG symptom development.

\section{LITERATURE CITED}

1. Calavan, E. C. 1961. Ferment gum disease (Rio Grande gummosis) of grapefruit. Calif. Citrog. 46:231-232.

2. Childs, J. F. L. 1978. Rio Grande gummosis disease of citrus trees. Part I. A brief review of the history and occurrence of Rio Grande gummosis. Plant Dis. Rep. 62:390-394.

3. Davis, R. M. 1988. Rio Grande gummosis. Page 67 in: Compendium of Citrus Diseases. J. O. Whiteside, S. M. Garnsey, and L. W. Timmer, eds. American Phytopathological Society Press, St. Paul, MN.

4. Fawcett, H. S. 1934. Is psorosis of citrus virus disease? Phytopathology 24:659-668.

5. Hebb, J. W., and Sonoda, R. M. 1992. For Florida grapefruit growers: Is gummosis becoming more of a problem? Citrus Ind. 73(7):28-29.

6. Roistacher, C. N. 1991. Graft-transmissible diseases of citrus. Handbook for Detection and Diagnosis. FAO, Rome.

7. Roistacher, C. N. 1992. Psorosis - a review. Pages 139-154 in: Proc. 12th Conf. IOCV. P. Moreno, J. V. Da Graca, and L. W. Timmer, eds. IOCV, Riverside, CA.

8. Sonoda, R. M., and Pelosi, R. R. 1990. Fungi in Rio Grande gummosis lesions and patterns of gummosis-affected grapefruit trees in Indian River area groves. Proc. Fla. State Hortic. Soc. 103:59-61.

9. Sonoda, R. M., Pelosi, R. R., and Hebb, J. W 1992. Comparing Rio Grande gummosis and citrus blight incidence on grapefruit on Swingle citrumelo rootstock. Proc. Fla. State Hortic. Soc. 105:28-32

10. Swingle, W. T., and Webber, H. J. 1896. The principle diseases of citrus fruits in Florida U.S. Dep. Agric. Div. Veg. Physiol. Pathol Bull. No. 8 .

11. Timmer, L. W. 1988. Psorosis. Pages 44-45 in: Compendium of Citrus Diseases. J. O Whiteside, S. M. Garnsey, and L. W. Timmer, eds. American Phytopathological Society Press, St. Paul, MN.

12. Wallace, J. M. 1945. Technique for hastening foliage symptoms of psorosis of citrus. Phytopathology 35:535-541. 